\title{
Bimodal pore size distribution of a high-plasticity compacted clay
}

\author{
G. J. BURTON*, D. SHENG* and C. CAMPBELL*
}

\begin{abstract}
The microstructure of compacted clay plays an important role in its hydraulic and mechanical behaviour. However, little experimental evidence is available for high-plasticity clay compacted on the wet side of the standard Proctor optimum water content. The results of an oedometric and microstructural investigation (mercury intrusion porosimetry) on reconstituted and compacted highplasticity clay are presented. The microstructural results indicate that a bimodal pore size density function is not limited to clays compacted on the dry side of the standard Proctor optimum. The compacted clay prepared on the wet side can display a bimodal pore size distribution dependent on the level of compaction, current void ratio and degree of saturation. The bimodal distribution of the compacted clay can be lost by compression to high vertical stress accompanied by an increase in the degree of saturation. In this case the compression path ultimately approaches the normal compression line of the reconstituted saturated material. The results demonstrate that the observed behaviour of the compacted clay can be interpreted with reference to the reconstituted clay.
\end{abstract}

KEYWORDS: compaction; expansive soils; fabric/structure of soils

ICE Publishing: all rights reserved

\section{INTRODUCTION}

The coupled hydraulic and mechanical behaviour of compacted clays plays an important role in the long-term functioning of infrastructure. Construction specifications directly impact the water content, void ratio, suction and degree of saturation developed during compaction and, as a result, the long-term performance and microstructure of compacted clay. For example, compacted clays prepared on the wet side of (i.e. water content greater than) standard Proctor optimum water content are commonly used as liners or in the core of embankment dams for their water retention ability. Daniel \& Benson (1990) demonstrated the essential considerations required to be taken into account in the selection of construction specifications for clayey fill used as liners.

The microstructure of compacted soil can be quantitatively investigated using the mercury intrusion porosimetry (MIP) technique. The derivative of cumulative mercury intrusion $\left(\delta \mathrm{e}_{\mathrm{MIP}} / \delta \log d\right)$ referred to as the pore size density (PSD) function, can be used to quantify and differentiate the microstructural arrangement of soils. The term pore size is used here to denote the apparent pore entrance diameter $(d)$. A single peak in the PSD function is indicative of a single dominant pore size or a unimodal PSD, while twin peaks in the PSD function indicate two dominant pore sizes or a bimodal PSD. A bimodal PSD is also sometimes referred to as an 'aggregated' or 'doubleporosity' structure. A characteristic bimodal PSD function is commonly reported for clays compacted on the dry side of (i.e. water content less than) the standard Proctor optimum water content (Juang \& Holtz, 1986; Delage et al., 1996). Conversely, clays compacted on the wet side of the standard Proctor optimum water content are assumed to be characteristically unimodal (Tarantino, 2011). The

Manuscript received 17 January 2014; first decision 20 February 2014; accepted 29 April 2014.

Published online at www.geotechniqueletters.com on 9 June 2014.

*School of Engineering, University of Newcastle, Callaghan, NSW, Australia microstructure of compact clay, however, depends on the relative position of the sample in the dry density $\left(\rho_{\mathrm{d}}\right)$ (or void ratio) versus water content $(w)$ plane following compaction (Toll, 2000; Delage et al., 2006; Merchán, 2011).

This article examines the results of an experimental study on a high-plasticity clayey soil. Reconstituted samples were compressed to four different vertical effective stresses, while compacted samples were prepared to cover a range of water contents spanning dry to wet of standard Proctor optimum water content. Constant water content (CWC) and constant suction compression results demonstrate the similarities in microstructure under both atmospheric and elevated pore-air pressures. The results are used to demonstrate the evolution of the microstructure with hydraulic and mechanical stress paths.

\section{METHODOLOGY}

A high-plasticity residual soil (Maryland clay) was tested under reconstituted and compacted states. The material comprised $17 \%$ sand, $27 \cdot 5 \%$ silt and $55 \cdot 5 \%$ clay, with a liquid limit of $69 \%$, plasticity index of $43 \%$ and specific gravity of $2 \cdot 65$. Standard Proctor compaction results are shown in Fig. 1, with a maximum dry density of $1.5 \mathrm{t} / \mathrm{m}^{3}$ (void ratio 0.76 ) and standard Proctor optimum water content of $24 \cdot 8 \%$. Further details of the Maryland experimental site and material can be found in the literature (Fityus \& Smith, 2004; Fityus et al., 2004). Reconstituted samples were prepared at an initial water content around 1.5 times the liquid limit and one dimensionally consolidated to a vertical effective stress of $50 \mathrm{kPa}$ (sample R0). Reconstituted samples were consolidated to maximum vertical effective stresses of $200 \mathrm{kPa}$ (R1), $600 \mathrm{kPa}$ (R2) and $2000 \mathrm{kPa}$ (R3 and R4). Compacted samples were prepared from dried powder to a water content of $28 \%$ and statically compacted to target void ratios of 1.27 (samples $\mathrm{C} 1-\mathrm{C} 8, \mathrm{C} 11$ ) and 1.0 (samples $\mathrm{C} 9$ and $\mathrm{C} 10$ ). The void ratio of 1.27 was chosen to closely match the initial void ratio of the reconstituted material following initial consolidation, while the void ratio of 1.0 


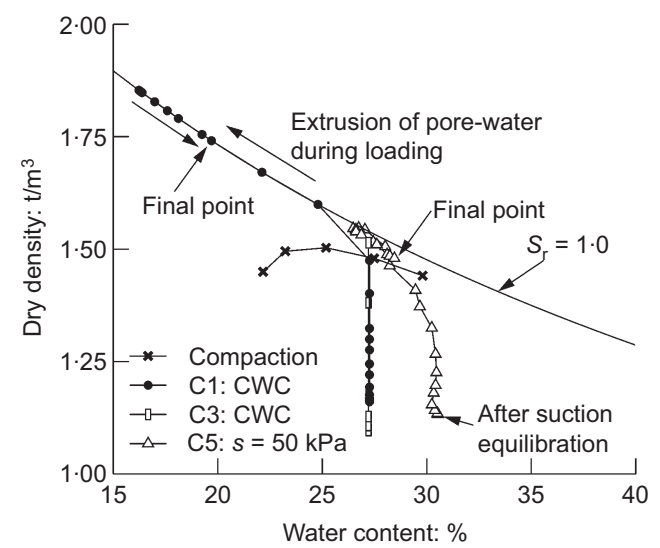

Fig. 1. Standard Proctor compaction results

was chosen to represent a higher degree of compaction. In addition, compacted samples with an initial void ratio of $1 \cdot 27$ and water contents of 25,21 and $19 \%$ (samples C12C14) were prepared to span wet and dry of standard Proctor optimum water content.

Compacted samples were tested under CWC and constant suction conditions. CWC compression was carried out to simulate a higher compaction energy and by minimising the potential for evaporation from the sample by sealing the oedometer cell with cling wrap. Top and bottom porous stones were initially dry prior to testing. As the stress level was increased and the void ratio reduced (increase in degree of saturation), extrusion of pore water from the sample into the top and bottom porous stones was allowed to occur, resulting in a lower final water content compared to the initial water content (for example, a reduction in water content of about $7 \%$ for sample $\mathrm{C} 1$ (see also Fig. 1)). Soaking was completed in test $\mathrm{C} 4$ by flooding the oedometer cell at a vertical net stress of $100 \mathrm{kPa}$.

Constant suction oedometer tests were completed using an axis-translation oedometer (Hoffman et al., 2005). Suctions of 50, 100 and $200 \mathrm{kPa}$ were imposed on samples with initial void ratios of $1 \cdot 27$ (C5, C6 and C7) and suctions of 50 and $100 \mathrm{kPa}$ were imposed on samples with an initial void ratio of 1.0 (C9 and $\mathrm{C} 10)$.

The degree of saturation shown in the microstructural results was calculated based on measurements of the initial and final water contents and final calculated void ratio. In the suction-controlled tests, pore-water volume changes during compression were recorded using a pressure/volume controller and the degree of saturation was estimated based on the calculated void ratio, updated pore-water volume and final measured water content.

MIP tests were conducted using an AutoPore IV 9500 (Micrometrics). All samples were unloaded from the oedometric condition prior to testing, representing a vertical stress condition of $0 \mathrm{kPa}$. Following unloading and prior to MIP tests, the samples were dehydrated by sublimation (Delage \& Pellerin, 1984). From the sample removed from the oedometer, small $\left(\approx 1 \mathrm{~cm}^{3}\right)$ specimens were cut with a wire saw for MIP testing. These specimens were immersed in liquid nitrogen followed by vacuum freeze drying at $-56^{\circ} \mathrm{C}$ and vacuum of $0.3 \mathrm{~Pa}$ for a period of about $48 \mathrm{~h}$. Intrusion of mercury was completed to a maximum injection pressure of $228 \mathrm{MPa}$ followed by controlled reduction of pressure (extrusion). The equivalent pore entrance diameter (d) was calculated using the Washburn equation (Washburn, 1921) assuming a mercury contact angle of $140^{\circ}$ (Romero, 1999).

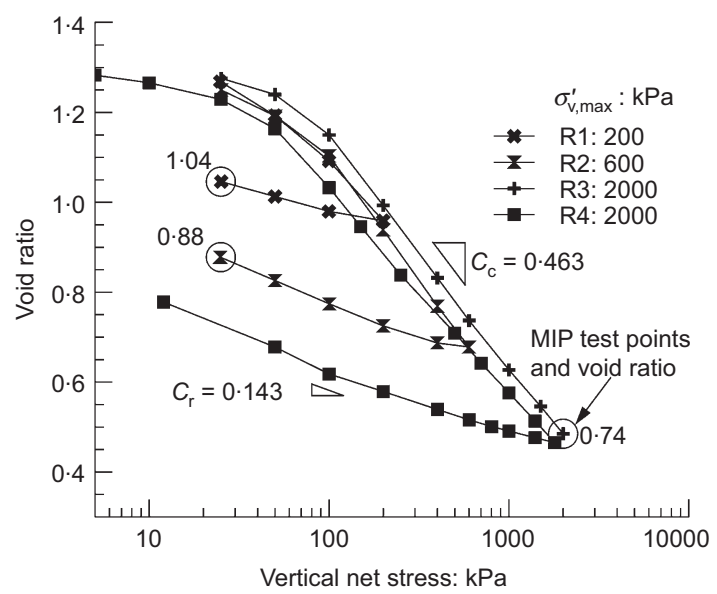

Fig. 2. Oedometric path of reconstituted samples

\section{COMPRESSION RESULTS}

Oedometric compression of the reconstituted and compacted samples is now examined. The results are presented in terms of void ratio $(e)$ and vertical net stress $\left(\bar{\sigma}_{\mathrm{v}}=\sigma_{\mathrm{v}}-u_{\mathrm{a}}\right.$, $\sigma_{\mathrm{v}}$ being the total vertical stress and $u_{\mathrm{a}}$ the pore-air pressure). The reconstituted sample is used as a reference state for interpreting the behaviour of the compacted samples and the oedometric paths of the reconstituted tests (R1-R4) are shown in Fig. 2. The reconstituted samples show a similar elastoplastic compression index $\left(C_{\mathrm{c}}\right)$ equal to $0 \cdot 463$ and elastic compression index $\left(C_{\mathrm{r}}\right)$ equal to $0 \cdot 143$. Some vertical shift of tests R3 and R4 was observed, possibly related to estimates of the initial void ratio (Rocchi \& Coop, 2014). Test R3 was rapidly unloaded (undrained) from the oedometer for sampling and MIP testing. The points at which samples were taken for MIP testing are shown in Fig. 2. The void ratio noted is the void ratio estimated based on the MIP test and some expansion of R3 was observed following rapid unloading (void ratio increased to $0 \cdot 74$ compared with the measured value at the end of the test of 0.48 ).

CWC compression results on compacted samples with atmospheric pore-air pressure $(\mathrm{C} 1-\mathrm{C} 4)$ prepared to a void ratio of $1 \cdot 27$ are shown in Fig. 3. The apparent yield stress for test $\mathrm{C} 1$ (CWC) was approximately $200 \mathrm{kPa}$. However, it should be noted that the true yield stress may be somewhat below this as the normal compression line (NCL) for nonzero pore-water pressure is curved in the net stress space

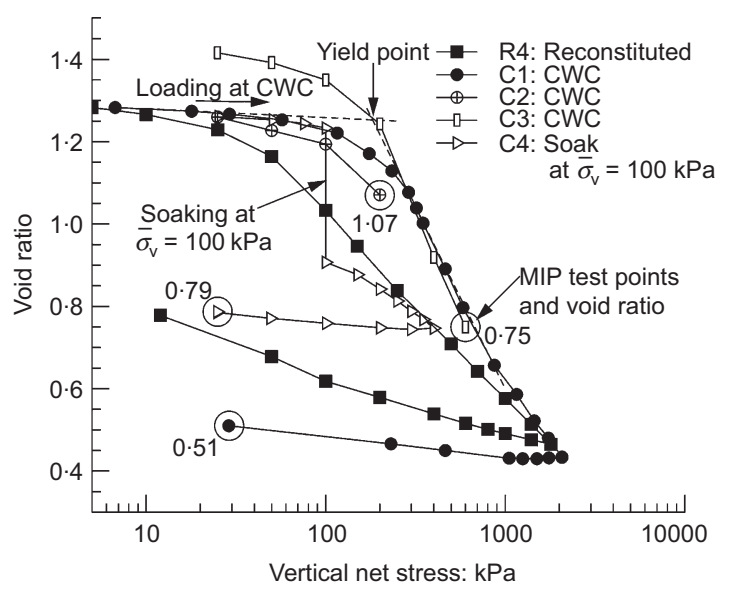

Fig. 3. Oedometric path of constant water content and soaking tests (atmospheric pore-air pressure) 
Table 1. Void ratios before and after rapid unloading

\begin{tabular}{l|c|c}
\hline \multirow{2}{*}{ Test } & \multicolumn{2}{|c}{ Void ratio } \\
\cline { 2 - 3 } & Pre-unloading (oedometer) & Post-unloading (MIP test) \\
\hline R3 & $0 \cdot 48$ & $0 \cdot 74$ \\
C2 & $1 \cdot 07$ & $1 \cdot 03$ \\
C3 & $0 \cdot 75$ & $0 \cdot 75$ \\
\hline
\end{tabular}

(Sheng, 2011). Sample C3 started with a higher initial void ratio but is included for comparison of the microstructural results. The compacted samples were able to maintain a higher void ratio than the reconstituted material at the same vertical stress. Soaking of sample $\mathrm{C} 4$ at a vertical stress of $100 \mathrm{kPa}$ (after CWC loading) induced significant elastoplastic compression of the sample with a void ratio somewhat below the NCL of the reconstituted sample. Subsequent loading to a vertical stress of $400 \mathrm{kPa}$ in Fig. 3 shows that the void ratio began to approximate that of the reconstituted sample as the vertical stress was increased.

For tests R3, C2 and C3 the calculated void ratios before and after rapid unloading are compared in Table 1 . The difference in void ratio, pre- and post-unloading, of the reconstituted sample (R3) and the compacted samples (C2 and $\mathrm{C} 3$ ) is attributed to the difference in the elastic compression index observed. In addition, tests C2 and C3 were unloaded in an unsaturated state compared with R3, which was saturated.

Constant suction compression tests (C5-C7) on the compacted samples prepared to an initial void ratio of 1.27 are shown in Fig. 4. This shows that the yield stress of sample C6 $(s=100 \mathrm{kPa})$ is higher than that of sample C5 $(s=50 \mathrm{kPa})$ if the yield stress is defined as the intersection point of two asymptotic lines approximating the compression curve. In both cases, however, it can be seen that the compression line begins to converge to the reconstituted sample (R4) as the stress level is increased and the degree of saturation approaches $100 \%$. Compacted sample C8 was loaded at a suction of $50 \mathrm{kPa}$ to a vertical net stress of $100 \mathrm{kPa}$. The apparent yield stress of C8 is somewhat larger than that of $\mathrm{C} 5$. A possible reason for this difference is the slightly lower degree of saturation for test $\mathrm{C} 8(0 \cdot 62)$ than test C5 $(0 \cdot 65)$. If the NCLs are straight lines for a constant degree of saturation (Zhou et al., 2012), a higher yield stress for a lower degree of saturation would be expected even if

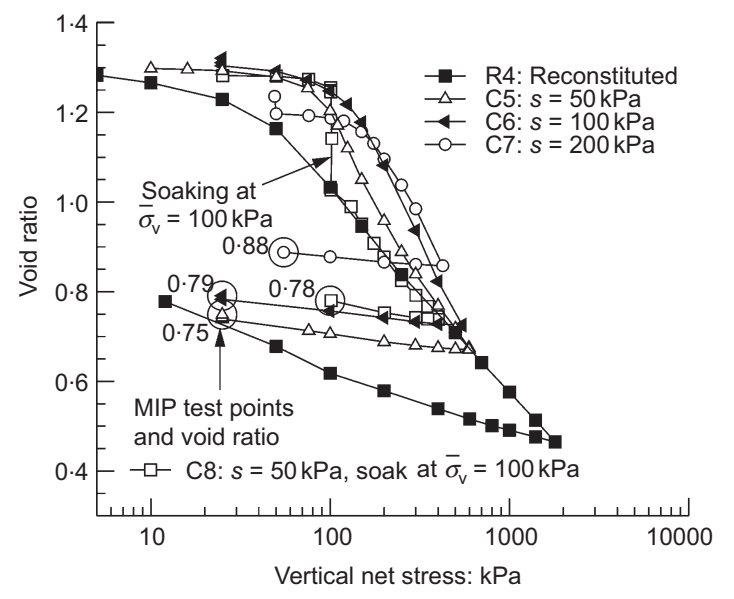

Fig. 4. Oedometric results - compacted samples, $e_{0}=1 \cdot 27$. Constant suction compression and wetting. C8: water injected to top of specimen while maintaining elevated pore-air pressure

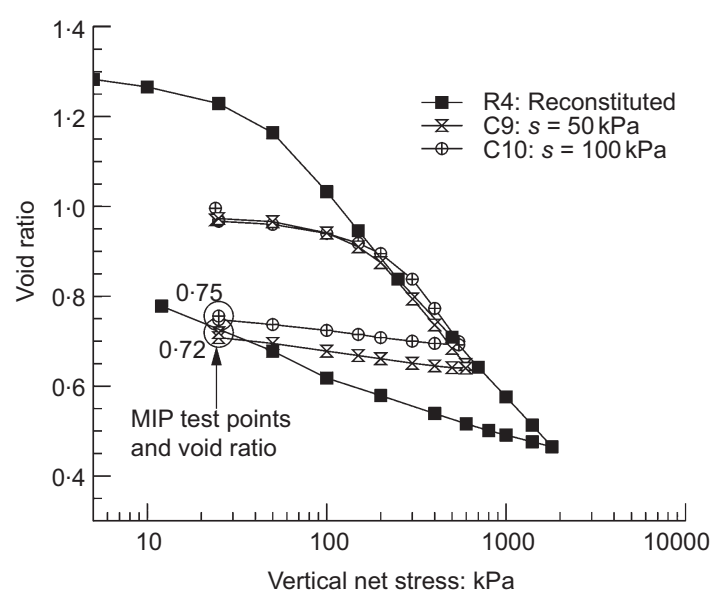

Fig. 5. Oedometric results - compacted samples, $e_{0}=1 \cdot 0$. Constant suction compression

the suction is held constant. Other possible reasons are the natural scatter in the experimental data or the inaccurate estimation of the yield stress for $\mathrm{C} 8$ due to the fact that loading was stopped at $100 \mathrm{kPa}$. The estimation of yield stress for unsaturated soils may not be straightforward, as pointed out by Sheng (2011). In test C8, suction was reduced in steps to $5 \mathrm{kPa}$ at a vertical stress of $100 \mathrm{kPa}$. Suction reduction, following equilibration of vertical displacement, with the axis-translation technique was unable to induce full collapse of the sample (i.e. to the NCL of the reconstituted material). To complete the test, water was injected to the top surface of the sample. While maintaining the elevated pore-air pressure, a pressure/ volume controller was used to inject water and flood the oedometer cell. At this point, constant suction was not maintained through the sample. The elevated pore-air pressure and constant suction was maintained for the remainder of the test to avoid unloading that may have occurred inadvertently due to pressure reduction. After injection of water, the axial stress, pore-air and pore-water pressures were held constant until equilibrium was attained. The sample collapsed to a void ratio close to the NCL of the reconstituted sample. This is in contrast to the result of test $\mathrm{C} 4$ with atmospheric pore-air pressure (Fig. 3), where the void ratio after soaking was below the NCL. After equilibration in test C8, loading was resumed (while maintaining the elevated pore-air pressure and a suction of $50 \mathrm{kPa}$ ) to a vertical stress of $400 \mathrm{kPa}$ followed by unloading. After soaking, the slope of the compression line approximated that of the reconstituted material.

For comparison, samples $\mathrm{C} 9$ and $\mathrm{C} 10$, prepared to an initial void ratio of $1 \cdot 0$, are shown in Fig. 5. The results show that the compression lines for the two suctions are almost coincident but, as the stress level increases, test $\mathrm{C} 10$ crosses the compression line of the reconstituted (R4). As the stress level is increased, however, the compression lines begin to converge.

\section{MICROSTRUCTURAL RESULTS}

The microstructural results of the reconstituted samples (R0-R3) are shown in Fig. 6. Starting with the initial state of the reconstituted sample (R0), which was consolidated to a vertical effective stress of $50 \mathrm{kPa}$, a single dominant pore entrance diameter of $3 \mu \mathrm{m}$ can be observed. Compression to progressively higher vertical stress reduces the total mercury intrusion volume $\left(e_{\mathrm{MIP}}\right)$, as shown in Fig. 6(a). The incremental peak is also progressively 


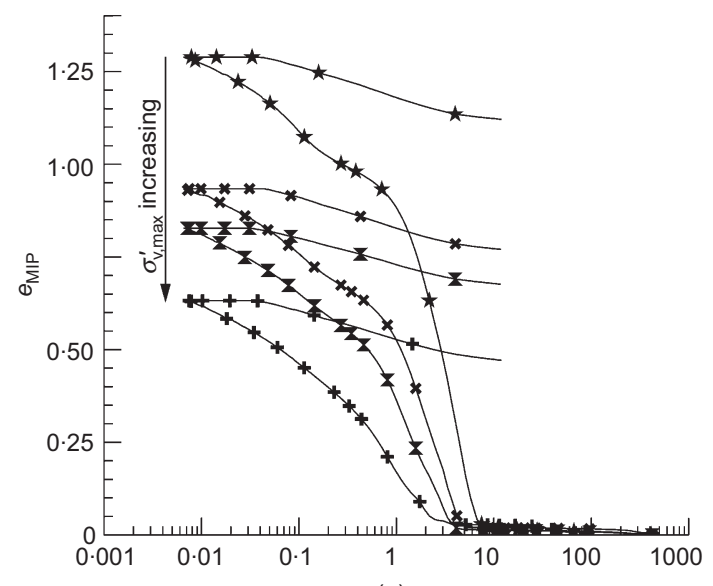

(a)

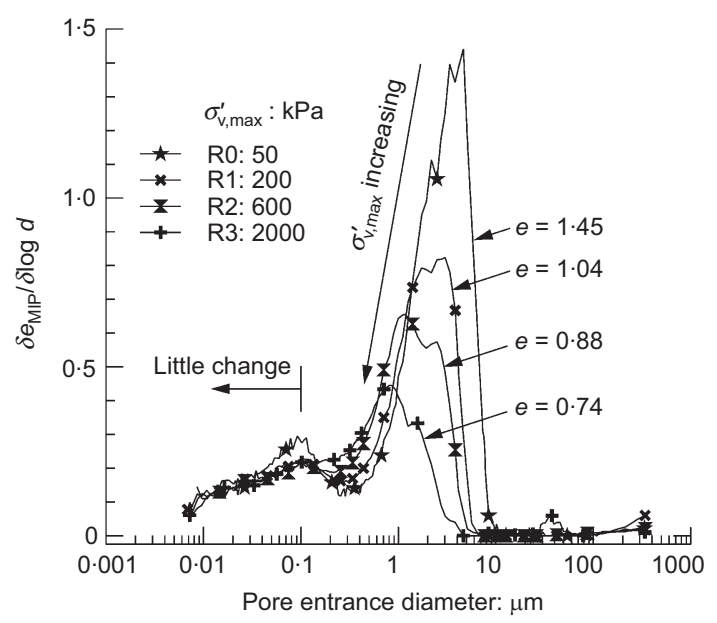

(b)

Fig. 6. Mercury intrusion results - reconstituted samples

reduced for higher vertical stress, as shown in Fig. 6(b). For diameters less than $0 \cdot 1 \mu \mathrm{m}$, there is little change in the incremental intrusion for the different vertical stresses. This highlights the fact that a reduction in void ratio occurs first at the expense of the largest pores within the soil.

For compacted samples (C11-C14) prepared to an initial void ratio of 1.27 , the MIP results clearly indicate a bimodal PSD in Fig. 7, regardless of the initial compaction water content. The degree of saturation for these tests was

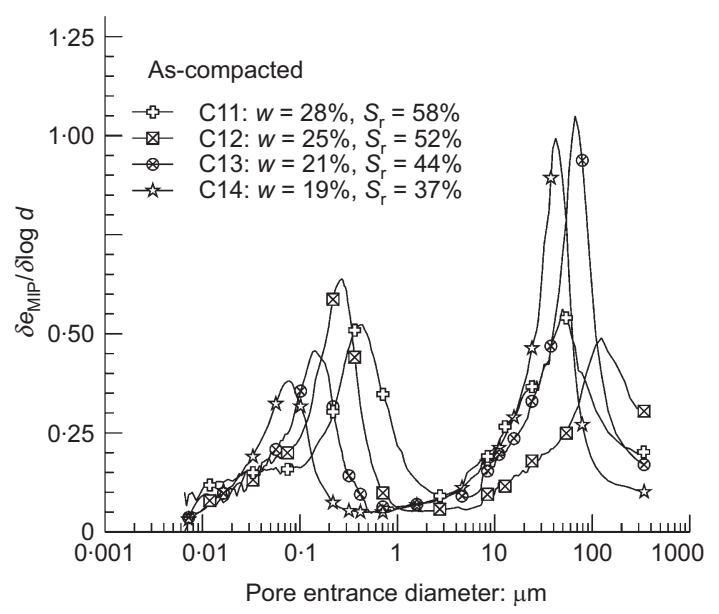

Fig. 7. PSD for different initial compaction water content and $e_{0}=1 \cdot 27$

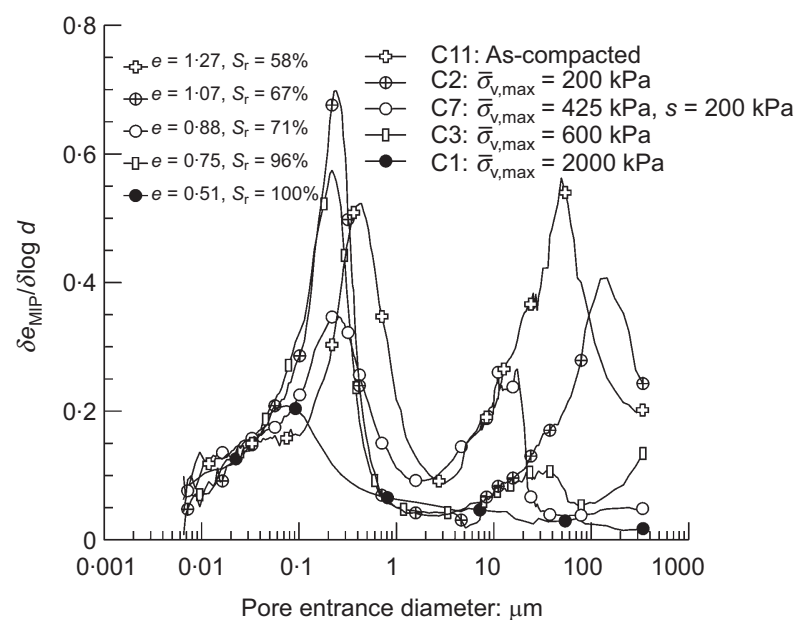

Fig. 8. PSD following CWC compression; initial water content $=28 \% ; e_{0}=1 \cdot 27$

below $58 \%$, as shown in the figure. Two peaks in the PSD function can be observed, one at a diameter of 0.078 $0.417 \mu \mathrm{m}$ and a second, presumed to be associated with macro-pores around $50 \mu \mathrm{m}$ diameter. Test $\mathrm{C} 12$ had a larger diameter for the macro-pore peak at around $125 \mu \mathrm{m}$. The reason for this increase is not immediately apparent, but may be related to the preparation of this sample (i.e. size of aggregates prior to compaction or the effects of trimming the sample prior to freeze drying). Microstructural results following CWC compression to vertical stresses of $200 \mathrm{kPa}$ (C2), $600 \mathrm{kPa}(\mathrm{C} 3)$ and $2000 \mathrm{kPa}(\mathrm{C} 1)$ with an initial water content of $28 \%$ are shown in Fig. 8 . A progressive increase in the degree of saturation is shown for the higher vertical stresses. Again, a larger diameter for the macro-pore peak is observed for sample $\mathrm{C} 2$ with a diameter of approximately $150 \mu \mathrm{m}$. However, the size of the peak is somewhat reduced for this pore domain compared with C11. Following compression, pore sizes greater than a diameter of $1 \mu \mathrm{m}$ are virtually all erased in sample $\mathrm{C} 3$, with a final void ratio close to the maximum dry density but above the NCL, and sample $\mathrm{C} 1$, with a void ratio lower than the maximum dry density but on the NCL. Sample C3 maintained some pores with diameter between 7 and $100 \mu \mathrm{m}$ and greater than $100 \mu \mathrm{m}$, which are perhaps representative of the void ratio in excess of the NCL. The erasure of the macro-pores, shown here in the results of CWC representative of compaction, is then indicative of convergence of the compacted compression line with the reconstituted and the progressive development of a unimodal PSD.

Microstructural results of suction-controlled tests prepared with initial void ratios of 1.27 (C5 and C6) and 1.0 (C9 and C10) are shown in Fig. 9. In the compression plane, these four samples had converged with the NCL. The microstructural results display a similar PSD for the four samples. Pore sizes greater than $10 \mu \mathrm{m}$ diameter developed during the compaction process were erased during compression at constant suction, similar to the $\mathrm{CWC}$ results $(\mathrm{C} 1$ and $\mathrm{C} 3)$. An increase in the dominant micro-pore diameter, from $\mathrm{C} 11$ as-compacted to a larger diameter is evident based on the applied suction: $1 \cdot 1 \mu \mathrm{m}$ at $50 \mathrm{kPa}$ suction (C5 and C9) and $0.55 \mu \mathrm{m}$ to $0.85 \mu \mathrm{m}$ at $100 \mathrm{kPa}$ suction (C6 and C10, respectively).

The two soaking tests - one soaked at a vertical stress of $100 \mathrm{kPa}$ under atmospheric air pressure (C4) and the other soaked at $100 \mathrm{kPa}$ under elevated pore-air pressure (C8) are shown in Fig. 10. The microstructural results are nearly coincident for both samples, with the peak of the 


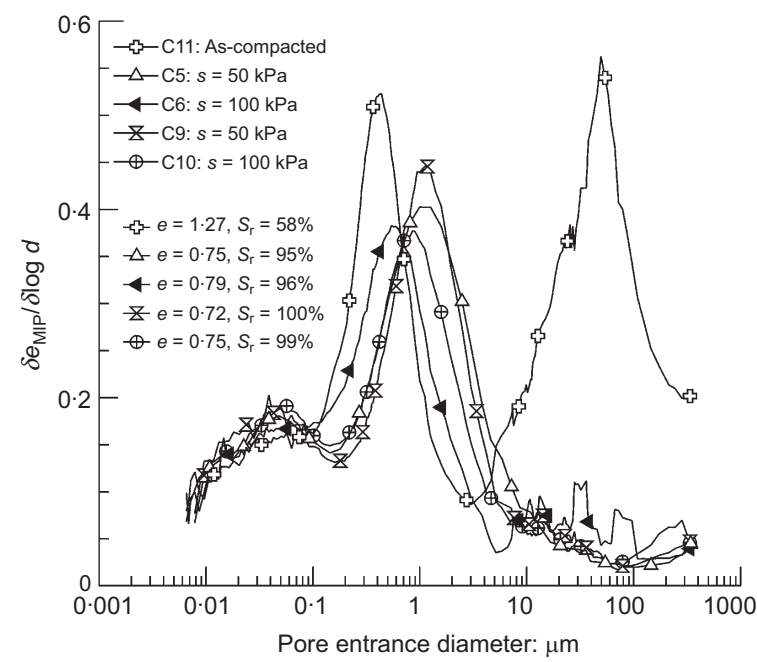

Fig. 9. PSD following constant suction compression; initial water content $=28 \% ; e_{0}=1 \cdot 27$

micro-pore domain around $1 \cdot 1 \mu \mathrm{m}$, comparable to the results of C5 and C9. Macro-pores larger than 10-20 $\mu \mathrm{m}$ diameter were erased during the combined process of compression and soaking.

\section{DISCUSSION}

A combined oedometric and microstructural investigation of reconstituted and compacted high-plasticity clay was conducted. The results of the reconstituted material show a progressive reduction in the dominant peak in the PSD with increasing stress level. The microstructural results of the material compacted on the wet side of the standard Proctor optimum water content show that a bimodal PSD may be developed during compaction. Thus, the characteristic bimodal pore size distribution is not limited to clays compacted on the dry side of the standard Proctor optimum water content. These results are compatible with the findings of Merchán (2011). An important consideration when interpreting the results is the void ratio and degree of saturation obtained by the sample following compaction.

Similar to the reconstituted material, compression of compacted material on the wet side of the standard Proctor optimum water content, under both $\mathrm{CWC}$ and constant suction conditions, leads to a progressive reduction in the volume of macro-pores. The reduction of macro-pores is representative of convergence of the compacted unsaturated material with the NCL. The macro-pores can conveniently be defined as pores of diameter greater than the reconstituted material at the same stress level. Compression of the compacted unsaturated soil then becomes analogous to that of naturally structured soils (e.g. Liu \& Carter, 2002).

The controlled-suction soaking test highlights that an applied suction (with the axis-translation technique) of very close to zero did not produce saturation. To induce collapse of Maryland clay, as evidenced by the result shown in Fig. 4, water was injected to flood the oedometer cell. Previous researchers have also observed that collapse was not induced until relatively low suction (e.g. Monroy et al., 2010).

This microstructural analysis has clearly demonstrated that compacted Maryland clay prepared to the wet side of optimum should not be treated as fundamentally different from the reconstituted material. Further work is required

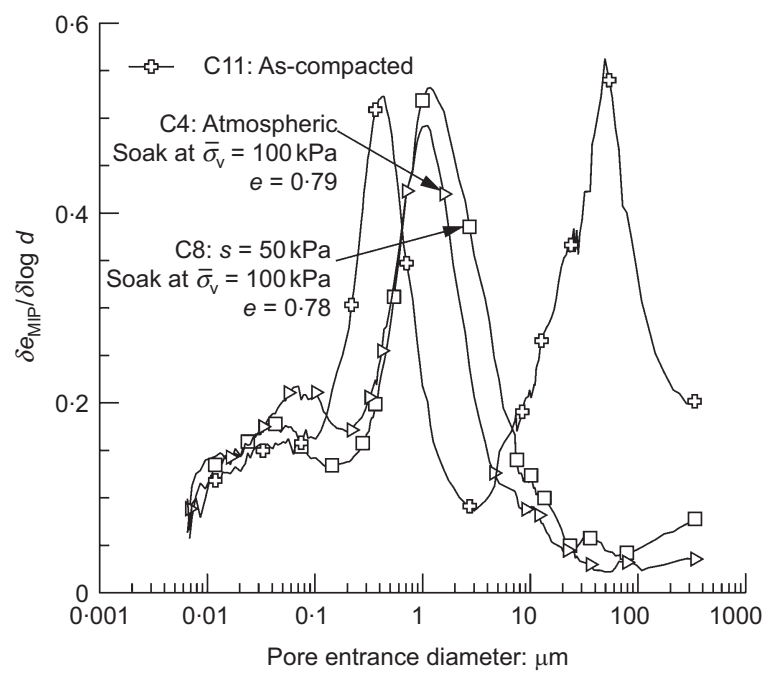

Fig. 10. PSD following soaking at atmospheric and elevated pore-air pressure; initial water content $=28 \% ; e_{0}=1 \cdot 27$

to confirm the same conclusion for samples prepared on the dry side, but it would appear that observed differences in the (compression) behaviour from the reconstituted material may be captured through incorporation of the degree of saturation (a state parameter) into the volume change equation.

\section{REFERENCES}

Daniel, D. \& Benson, C. (1990). Water content-density criteria for compacted soil liners. J. Geotech. Engng 116, No. 12, 1811-1830.

Delage, P. \& Pellerin, M. (1984). Influence de la lyophilisation sur la structure d'une argile sensible du Quebec. Clay Miner. 19, 151-160.

Delage, P., Audiguier, M., Cui, Y.-J. \& Howat, M. D. (1996). Microstructure of a compacted silt. Canad. Geotech. J. 33, No. $1,150-158$.

Delage, P., Marcial, D., Cui, Y. J. \& Ruiz, X. (2006). Ageing effects in a compacted bentonite: a microstructure approach. Géotechnique 56, No. 5, 291-304.

Fityus, S. G. \& Smith, D. W. (2004). The development of a residual soil profile from a mudstone in a temperate climate. Engng Geol. 74, No. 1-2, 39-56.

Fityus, S. G., Smith, D. W. \& Allman, M. A. (2004). Expansive soil test site near Newcastle. J. Geotech. Geoenviron. Engng 130, No. 7, 686-695.

Hoffman, C., Romero, E. E. \& Alonso, E. E. (2005). Combining different controlled-suction techniques to study expansive clays. In Advanced experimental unsaturated soil mechanics (Tarantino, A, Romero, E. E. \& Cui. Y. J. (eds)). London: Taylor \& Francis, pp. 61-67.

Juang, C. H. \& Holtz, R. D. (1986). Fabric, pore-size distribution and permeability of sandy soils. J. Geotech. Engng ASCE 112, No. 9, 855-868.

Liu, M. D. \& Carter, J. P. (2002). A structured Cam Clay model. Can. Geotech. J. 39, No. 6, 1313-1332.

Merchán, V. (2011). Small strain stiffness and residual strength of unsaturated Boom clay: a microstructural insight. $\mathrm{PhD}$ thesis, Universitat Politécnica de Catalunya, Spain.

Monroy, R., Zdravkovic, L. \& Ridley, A. (2010). Evolution of microstructure in compacted London clay during wetting and loading. Géotechnique 60, No. 2, 105-119.

Rocchi, I. \& Coop, M. R. (2014). Experimental accuracy of the initial specific volume. Geotech. Test. J. 31, No.1, 1-7.

Romero, E. (1999). Characterisation and thermo-hydro-mechanical behaviour of unsaturated Boom clay: an experimental study. $\mathrm{PhD}$ thesis, Universitat Politécnica de Catalunya, Spain.

Sheng, D. (2011). Review of fundamental principles in modelling unsaturated soil behaviour. Comput. Geotech. 38, No. 6, 757-776. 
Tarantino, A. (2011). Compacted versus reconstituted states. In Unsaturated soils (Alonso, E. E. \& Gens, A. (eds)). Boca Raton, FL: CRC Press, pp. 113-136.

Toll, D. (2000). The influence of fabric on the shear behaviour of unsaturated compacted soils. Advances in unsaturated geotechnics, 2000. Reston, VA: American Society of Civil Engineers, pp. $222-234$.
Washburn, E. W. (1921). Note on a method of determining the distribution of pore sizes in a porous material. Proc. Nat. Acad. Sci. USA 7, 115-116.

Zhou, A.-N., Sheng, D., Sloan, S. W. \& Gens, A. (2012). Interpretation of unsaturated soil behaviour in the stress saturation space, I: volume change and water retention behaviour. Comput. Geotech. 43, 178-187.

\section{WHAT DO YOU THINK?}

To discuss this paper, please email up to 500 words to the editor at journals@ice.org.uk. Your contribution will be forwarded to the author(s) for a reply and, if considered appropriate by the editorial panel, will be published as a discussion. 